Archives de sciences sociales des religions

136 | octobre - décembre 2006

Les Archives... cinquante ans après

Jean-Louis Ormieres, Politique et religion en France

Bruxelles, Éditions Complexe, 2002, 294 p.

Nicolas de Bremond d'Ars

\title{
CpenEdition
}

Journals

Édition électronique

URL : http://journals.openedition.org/assr/4008

DOI : $10.4000 /$ assr.4008

ISSN : 1777-5825

Éditeur

Éditions de l'EHESS

Édition imprimée

Date de publication : 1 décembre 2006

Pagination : 115-283

ISBN : 2-7132-2124-2

ISSN : 0335-5985

Référence électronique

Nicolas de Bremond d'Ars, " Jean-Louis Ormieres, Politique et religion en France », Archives de sciences sociales des religions [En ligne], 136 | octobre - décembre 2006, document 136-81, mis en ligne le 14 février 2007, consulté le 21 septembre 2020. URL : http://journals.openedition.org/assr/4008 ; DOI : https://doi.org/10.4000/assr.4008

Ce document a été généré automatiquement le 21 septembre 2020

(c) Archives de sciences sociales des religions 


\section{Jean-Louis Ormieres, Politique et religion en France}

Bruxelles, Éditions Complexe, 2002, 294 p.

Nicolas de Bremond d'Ars

1 L'ouvrage de J.-L. Ormières s'intéresse à la relation entre la politique et le catholicisme de 1789 à nos jours. Il s'efforce de retracer la difficile évolution entre l'Église catholique et l'État : du conflit à la neutralité, en passant par les différents équilibres provisoires du XIX ${ }^{e}$ siècle et la rupture définitive de la séparation.

2 Trois parties organisent les huit chapitres et en donnent la tonalité : «L'affrontement de l'Église et de l'État » (de la Révolution de 1789 à Mac Mahon en 1873), « Laïcisation et séparation de l'Église et de l'État» (1873-1905), «de la Séparation au désenchantement" (1905-1995). L'objectif est de "voir si, et dans quelle mesure, le profond processus de sécularisation en cours en France comme dans les autres pays européens délie le religieux du politique » (p. 8).

3 Compte tenu du format du livre (environ 220 p.), sans doute, l'exposition des données historiques est plus souvent linéaire et factuelle qu'analytique ou synthétique. De ce fait, l'ouvrage ne présente pas un intérêt particulier. Le xix siècle est parcouru rapidement, et l'auteur fait l'impasse sur des données considérables, en particulier celles ayant trait au financement de la religion, à l'évolution des personnels ecclésiastiques et religieux, ainsi qu'aux divisions internes au catholicisme (rôle de L'univers, dans la querelle ultramontaine, au Xix ${ }^{e}$ siècle). On préférera par exemple, sur cette période, les travaux de Jacqueline Lalouette. Le $\mathrm{xx}^{\mathrm{e}}$ siècle est lui aussi présenté de façon rapide. De ce fait, l'ouvrage sera plus utile à ceux qui voudront se mettre (ou se remettre) en mémoire les grandes lignes des rapports entre l'Église catholique et les différents gouvernements de la France. Malheureusement, ce survol ne permet pas à l'auteur de valider ni d'infirmer son projet sur la relation au politique du catholicisme français. 